\title{
Spatial and environmental analysis of Mycobacterium avium infected dairies in Antioquía (Colombia)
}

\author{
Correa, N.M.; ${ }^{1}$ Badel, M.J.'; Fernández, J.A. ${ }^{1}$ \\ Escuela de Medicina Veterinaria, Facultad de Ciencias Agrarias, \\ Universidad de Antioquia, Medellín, Colombia ${ }^{1}$. Skandha EIT SAS ${ }^{2}$. \\ E-mail: jorge.fernandez@udea.edu.co
}

\begin{abstract}
Correa, N.M.; Badel, M.J.; Fernández, J.A.: Spatial and environmental analysis of Mycobacterium avium infected dairies in Antioquia (Colombia). Rev. Vet. 32: 2, 155-163, 2021. The present study aimed to describe the spatial distribution of Mycobacterium avium subsp. paratuberculosis (MAP) in dairy herds, and to detail environmental variables taken as reference of the physical background of the study area, specifically those related to MAP-qPCR positive herds located in six municipalities of the northern region of the Province of Antioquia (Colombia), based on environmental sampling and qPCR analysis. The study herds (n $=386$ ) were located in 63 different districts from six municipalities. Participant herds were visited once between June and October (2016) to collect an environmental sample, and identification of MAP was achieved using a duplex quantitative real-time PCR method. Rainfall trends, day and nighttime surface temperature, and vegetation cover index were taken as environmental references of the physical background of the study area. In addition, distribution maps of MAP-qPCR positive and negative herds, as well as maps of temperature variations and vegetation cover, were constructed. As a result, there was an increase in MAP-positive herds in the North-West, South, and Southeast of the study area. An overall high rainfall regime was found and day- and nighttime surface temperatures showed important variations during sampling months. No evidence of management of the vegetation cover was found, in both pastures and areas with native vegetation, except for a conservancy area. In conclusion, the general environmental conditions, where the detection of MAP-positive herds is most likely to happen, were reported herein, considering approaches using the same (or a very approximate) sample collection and handling, and molecular detection method.
\end{abstract}

Key words: environment, geostatistics, Johne's disease, rainfall, surface temperature, vegetation cover.

\begin{abstract}
Resumen
Correa, N.M.; Badel, M.J.; Fernández, J.A.: Análisis espacial y ambiental de lecherías infectadas con Mycobacterium avium en Antioquía (Colombia). Rev. Vet. 32: 2, 155-163, 2021. El presente estudio tuvo como objetivo describir la distribución espacial de Mycobacterium avium subsp. paratuberculosis (MAP) en hatos lecheros, y detallar variables ambientales tomadas como referencia de los antecedentes físicos del área de estudio, específicamente aquellas relacionadas con los hatos positivos por MAP-qPCR, ubicados en seis municipios de la región norte de la Provincia de Antioquia (Colombia), de acuerdo con el muestreo ambiental y análisis por qPCR. Los hatos del estudio $(n=386)$ se ubicaron en 63 distritos diferentes de seis municipios. Los hatos participantes fueron visitados una vez entre junio y octubre (2016) para recolectar una muestra ambiental, y la identificación de MAP se logró utilizando un método de PCR cuantitativa dúplex en tiempo real. Las tendencias de 1luvia, la temperatura de la superficie diurna y nocturna, y el índice de cobertura vegetal se tomaron como referencias ambientales del entorno físico del área de estudio. Además, se construyeron mapas de distribución de hatos positivos y negativos a MAP-qPCR, así como mapas de variaciones de temperatura y cobertura vegetal. Como resultado, hubo un aumento en los hatos positivos para MAP en el noroeste, sur y sudeste del área de estudio. Se encontró un régimen general de alta precipitación y las temperaturas superficiales diurnas y nocturnas mostraron variaciones importantes durante los meses de muestreo. No se encontró evidencia de manejo de la cubierta vegetal, tanto en pastizales como en áreas con vegetación nativa, excepto en un área de conservación. En conclusión, se reportan las condiciones ambientales generales, donde es más probable que ocurra la detección de hatos positivos para MAP, considerando enfoques que utilizan el mismo (o uno muy aproximado) método de recolección y manejo de muestras, así como el método de detección molecular.
\end{abstract}


Palabras clave: cubierta vegetal, enfermedad de Johne, geoestadística, 1luvia, medio ambiente, temperatura superficial.

\section{INTRODUCTION}

Paratuberculosis (PTB) is on the World Organization for Animal Health (OIE) list of diseases. PTB refers to a chronic infection affecting cattle and other ruminants and is caused by Mycobacterium avium subsp. paratuberculosis (MAP) ${ }^{20}$.

The factors favoring spread among animals and transmission to humans are currently under investigation $^{11}$. Infectious animals shedding MAP in feces and thereby and thereby spreading the bacterium to susceptible hosts from an environmental source is the main strategy of transmission ${ }^{20}$.

MAP is thought to be an obligate parasitic pathogen of mammals, so the bacterium can persist in soil and water but does not multiply outside the host ${ }^{14}$. Renewed global commitment has led to an impulse to attain comprehensive data on animal infectious diseases distribution and intensity.

Once survey data have been collected, they can be integrated into a Geographical Information System (GIS) for mapping and further analysis, thus helping guide available resources to be most rationally and cost-effectively deployed.

At the same time, research into the spatial distribution of diseases has become a standard requirement of government agencies, since modern methods of disease mapping allow to infer if there are high-risk areas ${ }^{13}$.

Among them, geostatistics has been consolidated as one of the most solid and reliable tools for the analysis of this type of data, especially when the concepts of classical statistics are insufficient or when dealing with not-necessarily random variables, as often happens in the case of observational data.

Results deriving from geostatistical mapping and the conditional simulation that accompanies it can point to an environmental exposure characterization, being also helpful in the identification of geographical patterns and in the exploration of herd-level infection predictors for MAP.

In the Colombian instance, the identification of areas where MAP seems to be concentrated or potentially detected could allow policy-makers to implement targeted screenings and interventions since it is a notifiable disease in Colombia since 2015. However, the spatial distribution of MAP in Colombia has never been examined.

Therefore, the objectives of this study were: (a) to describe the spatial distribution of MAP in dairy herds, and (b) to describe environmental variables taken as reference of the physical background of the study area, specifically those related to MAP-qPCR positive herds located in six municipalities of the Northern region of the Province of Antioquia (Colombia), based on environmental sampling and qPCR analysis.

\section{MATERIAL AND METHODS}

\section{Study design and data}

The data was collected during a randomized crosssectional study carried out in the Northern region of the Province of Antioquia (Colombia). Herds of study were distributed in districts inside six municipalities (San José de La Montaña, Belmira, Santa Rosa de Osos, Entrerríos, San Pedro de Los Milagros and Donmatías)

The herd was considered as the unit of analysis Optimum and proportional allocation both at municipality and district-level were considered in the study design, therefore, 386 herds in 63 districts were randomly selected.

The study area is located between 1,090 and 2,979 m.a.s.l. and the temperature ranges from 12 to $16^{\circ} \mathrm{C}$ during the year. According to the Caldas-Lang climate classification, the study areas are classified as cold-wet and cold very humid. The study area belongs to the Medio Cauca/Alto Nechí watershed, which has a bimodal rainfall regime, with a dry season slightly marked in the mid-year and a second semester (September to November) with a higher rainfall level ${ }^{8}$.

\section{Environmental sample collection and laboratory} analysis

The participating herds were visited once and environmental sampling was done in each herd of study, from July to October 2016. The distribution of samplings between months was as follows: July $(53.2 \%$; 205/386), August (14.8\%; 57/386), September (23.4\%; 90/386), and October $(8.6 \% ; 33 / 386)$.

Each environmental sample contained samples from a single pool of at least six different sites of concentration of adult cattle, high traffic areas (e.g. areas surrounding waterers and feeders, areas surrounding the current mobile milking-unit place), and wastewater storage lagoons - when it was available at the herd, as previously reported $2,3,5,10,15,16,21,25$, with differences in the sampling methodology due to particularities in the management systems and facilities in the region of study, as well, as budget restrictions.

Identification of MAP was achieved using a duplex quantitative real-time PCR method (qPCR; Bactotype MAP PCR Kit ${ }^{\mathbb{D}}$, Qiagen). Procedures were carried out following the instructions of the manufacturer. A herd was considered as MAP infected if the environmental sample was found positive by the qPCR.

\section{Spatial analysis}

A polygon shapefile for Colombia's administrative boundaries at the district level was obtained from the Instituto Geográfico Agustín Codazzi (IGAC) website (https://www.igac.gov.co/). The boundaries of the districts required for the study were selected. All of the 
extracted data were linked and georeferenced with the district polygons using QGIS software (v.2.18.13, Las Palmas). The study area was subdivided into fixed spatial units (lattices), in which disease counts are observed in a fixed time period (July to October 2016).

The dependent variable was the number of MAPqPCR positive herds in each municipality, based on an anti-logarithmically transformed $\mathrm{Ct}$ values, reported for each herd. District-level location data (latitude, longitude) were included as independent variables. A semivariogram analysis was used to investigate the spatial structure and spatial autocorrelation in the data ${ }^{1}$.

In order to provide a continuous description of the covariance structure, a spherical spatial model was fitted to empirical variogram points using nonlinear least squares. Maps of temperature variation were constructed according to interpolations made based on semivariograms of the mean of the values at each sampling point with MAP-qPCR positive herds.

The interpolation method was $2 \times 2$ ordinary krigeage of the isotropic model. The processing of the information was carried out with the GS+TM software (v.10, Gamma Design Software, Plainwell, MI, USA).

Once the image was chosen, the processing was carried out to obtain the Normalized Vegetation Index (NDVI) ${ }^{26}$, which is used to estimate the quantity, quality, and development of the vegetation based on the measurement of the intensity of the vegetation and radiation of certain bands of the electromagnetic spectrum; its reading goes from -1 to 1 , where values below zero $(0)$ indicate the presence of water or soils saturated by humidity, and those between $0-1$ indicates different densities of vegetation cover ${ }^{7}$.

As a complement to the analysis, the Normalized Water Differential Index (NWDI), defined as the amount of water the vegetation has or the level of moisture saturation hat the soil has ${ }^{7}$, was also obtained, ranging from -1 to 0 .

\section{Environmental analysis}

In order to identify potential environmental conditions related to the presence of MAP in environmental samples analyzed by qPRC, this study included measures of rainfall trends, day and nighttime surface temperatures, and vegetation cover index providing a physical background of the whole study area.

The selection of these variables was exploratory according to previously published studies on the role of environmental and soil factors' influencing MAP survival outside the host, as well as its availability to the public.

The analysis of rainfall trends in the region considered data available from the tropical rainfall measuring mission (TRMM) with a spatial resolution of $4.3 \mathrm{Km}$, and GPM core observatory (spatial resolution of 11.1 $\mathrm{Km}$ ). The analysis was performed at a general level and specified according to the months of sampling and for November which served as a benchmark for the analysis of the vegetation cover index.
Day and nighttime surface temperatures are defined as the air column found between the ground and up to about $2 \mathrm{~m}$ high. Data from the moderate resolution imaging spectroradiometer (MODIS) sensors and the TRMM mission, between July and November (2016) were used.

Historical data from November were taken as reference for the spatial analysis of the vegetation cover index, whose set of satellite images correspond to that month, according to the portal of the Laboratorio de Sensoriamento Remoto Aplicado à Agricultura e Floresta $(L A F)$ of the Instituto Nacional de Pesquisas Espaciais (INPE) of Brazil, which makes them available for South America ${ }^{6}$

The MODIS data (MOD11 -temperature and emissivity, spatial resolution of $1.0 \mathrm{Km}$ ) are available from the Land Processes Distributed Active Archive Center (LPDAAC/U.S. geological survey-USGS: https://deltas. usgs.gov/fm/data/data_ndwi. aspx), Earth Resources Observation Science (EROS) center (https://1pdaac. usgs.gov).

The TRMM data (3B43V6; spatial resolution: 4.3 $\mathrm{Km}$ ) are available from the GES DISC distributed active DAAC file system as part of the Data and Information Services Center (DISC) of NASA's Goddard Earth Sciences (GES). The GPM core observatory provides a precipitation data product, available through the Giovanni portal of NASA (https://pmm.nasa.gov/dataaccess/downloads/gpm).

A satellite image of the region that fulfilled minimum requirements of cloudiness (less than $10 \%$ in the area of interest) and of approximate date to the range of months sampled, was searched. The chosen scene was a one from the collection LANDSAR 7 ETM + (level 1), obtained through the portal U.S. geological survey (USGS: https://earthexplorer.usgs.gov/). The best set of images found, close to the sampling dates was November $21^{\text {st }}, 2016$. The set of images chosen was the one cataloged as: and

LE07_L1TP_009055_20161121_20170112_01_T1,

LE07_L1TP_009056_20161121_20170112_01_T1.

All data on environmental variables were examined for biologically implausible entries (those unlikely to be true). Any erroneous data (those incorrect, detected during the editing process of the database) were removed or corrected. Descriptive statistics were computed for all the variables of interest, and significant differences $(p<0.05)$ were assessed using a Student's t-test.

\section{RESULTS}

The IS900-qPCR produced 25 positive $(\mathrm{Ct} \leq 40)$ and 361 negative results $(\mathrm{Ct}>40$ or not detected/reported by the software) from 386 environmental samples examined. Twenty-four of the 25 herd-level positive re- 
Table 1. Frequency of Mycobacterium avium subsp. paratuberculosis in 386 dairy herds located in the northern region, Province of Antioquia, Colombia (2016).

\begin{tabular}{lccc}
\hline Municipality & $\begin{array}{c}\text { sample } \\
\text { weight* } \\
(\%)\end{array}$ & $\begin{array}{c}\text { study } \\
\text { herds } \\
(\mathrm{n})\end{array}$ & $\begin{array}{c}\text { positive } \\
\text { herds } \\
\mathrm{n}(\%)\end{array}$ \\
\hline San José de la Montaña & 4.4 & 17 & $2(8)$ \\
Belmira & 8.8 & 34 & $2(8)$ \\
Santa Rosa de Osos & 38.2 & 147 & $1(4)$ \\
Entrerrios & 15.1 & 58 & $6(28)$ \\
San Pedro de los Milagros & 23.6 & 91 & $8(28)$ \\
Donmatías & 9.9 & 39 & $6(24)$ \\
\hline total & 100 & 386 & $25(6,5)$ \\
\hline
\end{tabular}

*according to foot-and-mouth disease vaccination records ${ }^{5}$.

sults were from the samples collected during July 2016, while one of the positive results was from the samples collected during September 2016. Overall and by-municipality frequencies are shown in Table 1 . The study area, as well as the distribution of MAP-positive and negative dairy herds, are shown in Figure 1.
The semivariogram obtained from the spatial distribution of the MAP-qPCR positive herds indicated a natural phenomenon that only complies with the hypothesis of intrinsic stationarity, pointing that the spatial distribution of the positive data is better adjusted to an anisotropic model (for this case, spherical), with the following results: an effect nugget of $5.3 \times 10^{-3}$ and a structural variance (Sill) of $1.75 \times 10^{-2}$.

The model has a low coefficient of determination $(\mathrm{r} 2=0.146)$, but an acceptable ratio between Nugget and Sill $(0.30)$. Theoretically, it is accepted that the model correctly interprets the reality if the difference between Nugget and Sill does not exceed 50\% (0.5)

With anisotropy included in the model, the estimated range was between $279.4 \mathrm{Km}\left(118^{\circ}\right.$ azimuth in

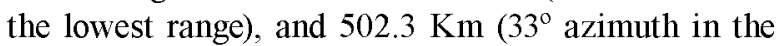
highest range), considering each grade of range in the semivariogram as equivalent to $111,045 \mathrm{Km} ; 2,516$ and $4,523^{\circ}$ (in the four directions North-West, North-East, East, South-East).

The lowest range corresponds to the lowest average variance $\left(3.125 \times 10^{-3}\right)$, and in the highest range, the highest average spatial variance $\left(9.882 \times 10^{-3}\right)$. Accord-

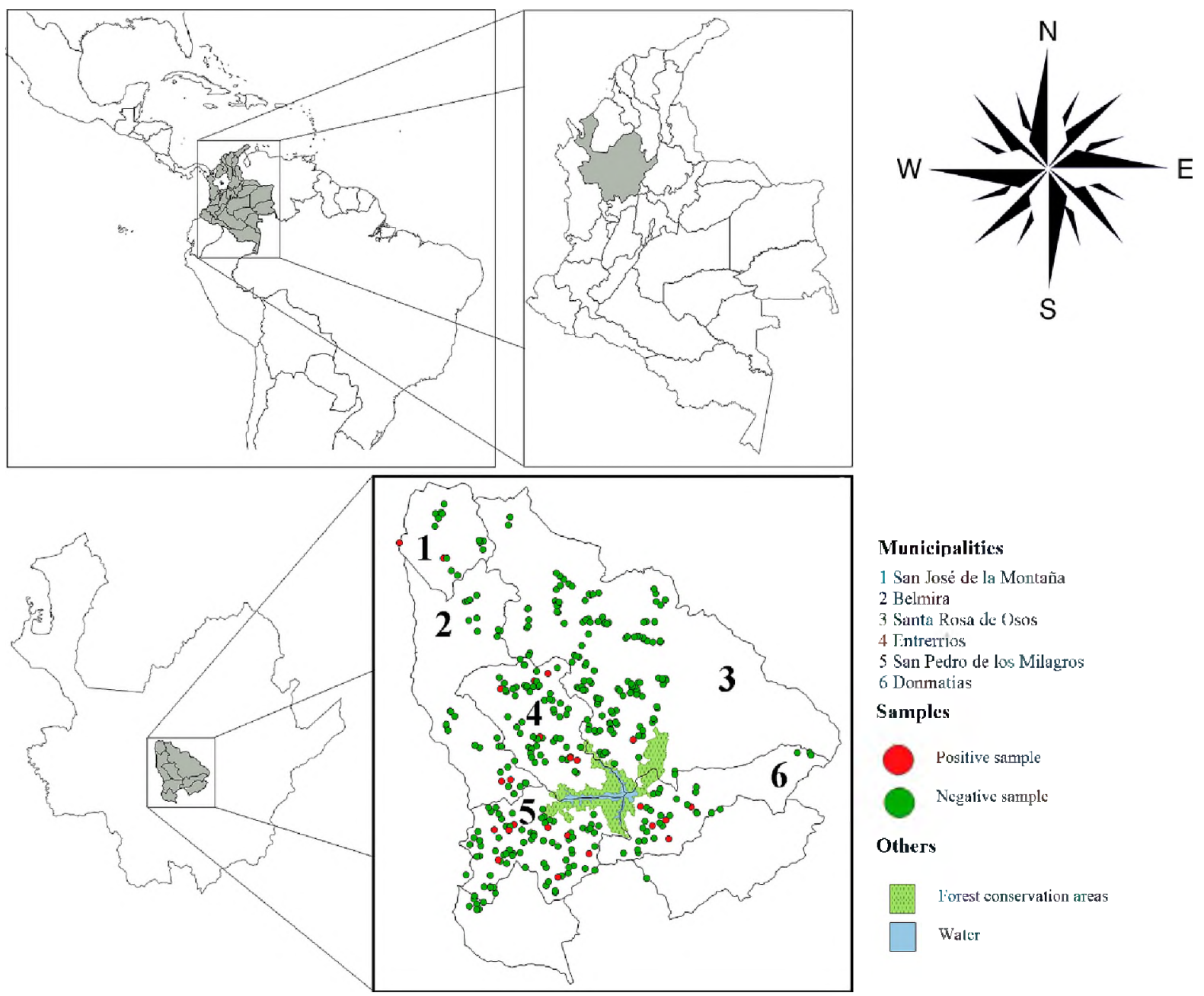

Figure 1. The geographic location of the six municipalities and the 386 dairy herds sampled in the Northern region, Province of Antioquia, Colombia (2016). 
ing to both sub-figures seen in Figure 2, there is an increase in positive reports in the North-West / South / South-East directions.

Figure 3 shows the maps of the spatial variation for day and nighttime surface temperature, according to the average at each point, considering the reports of positive herds and the values observed between July and October 2016. It is observed that the highest day-time surface temperature areas (between 20 and $20.8^{\circ} \mathrm{C}$ ) also present the highest nighttime temperature values (between 5.07 and $9.17^{\circ} \mathrm{C}$ ). However, in an area to the West — where the average surface temperature falls to negative values, moderate average values were present during the day $\left(18.6\right.$ and $19.3^{\circ} \mathrm{C}$ ). These findings suggest a thermal anomaly in such areas. However, with the available data and the characteristics of this work, it is not possible to confirm such a situation.

Figure 4 shows the spatial distribution of the vegetation cover (Figure 4a), obtained by applying the NDVI (Figure 4b) and the NDWI (Figure 4c). The false-color image (Figure 4a) allows visualizing the current condition of the vegetation cover, where there is no evidence of pasture management nor of natural areas that allow some degree of soil protection.
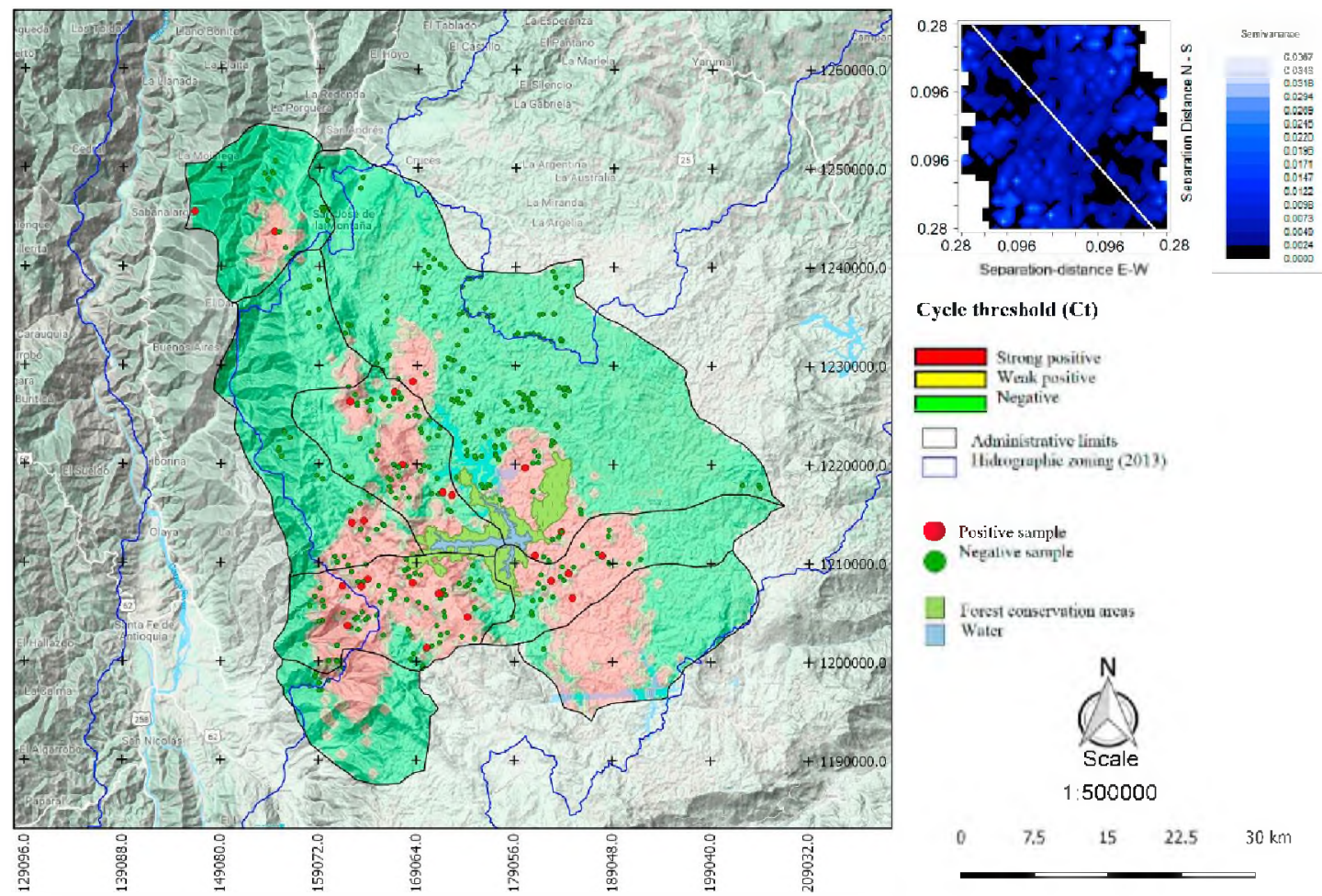

Cycle threshold (Ct)

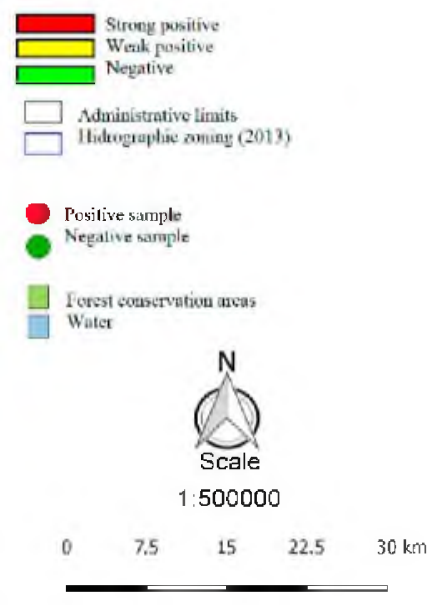

Figure 2. Simulation map of predicted distribution for MAP-qPCR positive herds (July to October 2016). The white line of the semivariance anisotropic map shows the flux direction with the lowest variance.
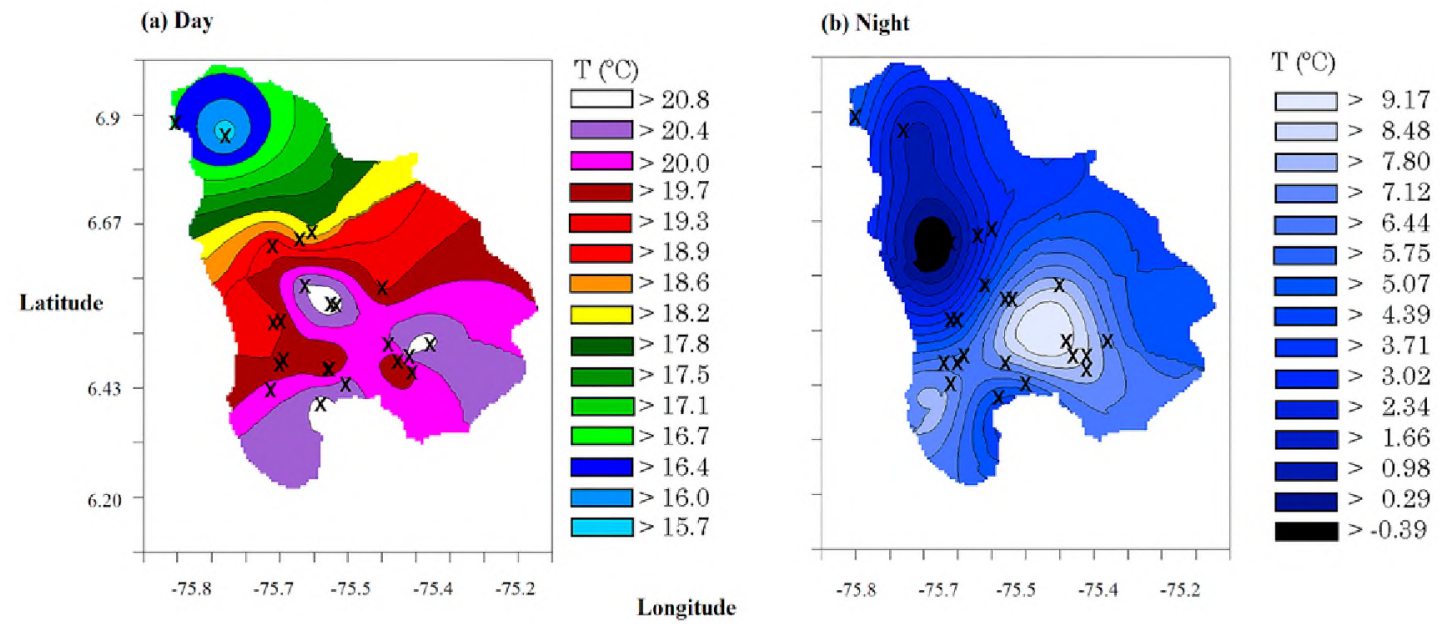

Figure 3. Spatial variation of the surface temperature $\left({ }^{\circ} \mathrm{C}\right)$ of the six municipalities and the 386 dairy herds sampled in the Northern region, Province of Antioquia, Colombia (2016). 


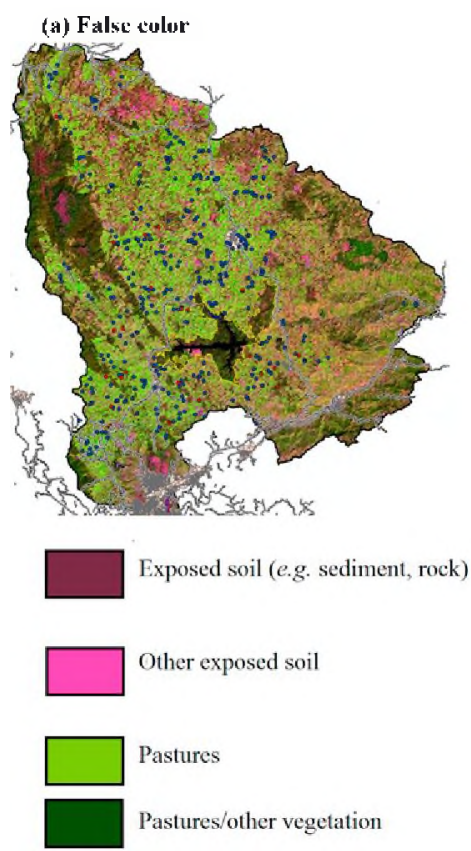

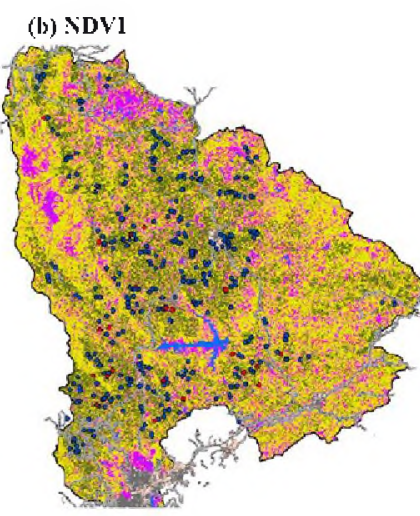

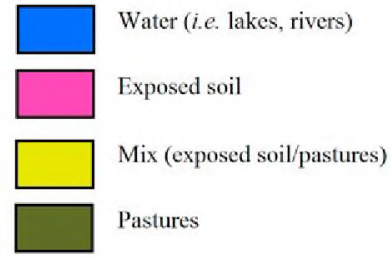

(c) NDWI $(-1 / 1)$

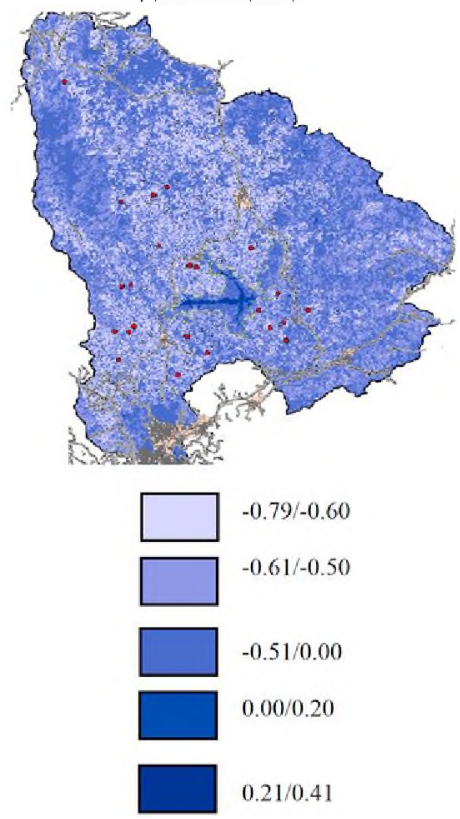

Figure 4. Vegetation cover (NDVI) and Moisture Saturation Index (NDWI) of the six municipalities and the 386 dairy herds sampled in the northern region, Province of Antioquia, Colombia (2016).

With the first index (Figure $4 b$ ) it is observed that the native vegetation is practically nonexistent and that the pastures are immersed in a matrix of exposed soil. When comparing the humidity between the different types of vegetation cover (Figure $4 \mathrm{~b}$ vs Figure $4 \mathrm{c}$ ), it can be observed that the areas with the highest grass density are precisely those with the lowest moisture density, while the wetter areas correspond better with the right areas (exposed soil/pastures).

According to the descriptive results of the rainfall trends at the MAP-qPCR positive dairy herds of study (material upon request), the average rainfall trends for the MAP-qPCR positive herds was high (average of $233.3 \mathrm{~mm} / \mathrm{month}$ ), according to the time series of the 2002-2017 monthly accumulated index.

In addition, the sampling months presented high values compared to the historical trend of the mean. In general, it is accepted that the rainfall conditions of November 2016 fit well with those observed during the sampling months. This is important when interpreting the condition of the vegetation, carried out, as previously mentioned, by a set of satellite images of that month.

September stands out with the maximum monthlyaccumulated $(306.4 \mathrm{~mm})$, and July with the minimum monthly-accumulated $(185.8 \mathrm{~mm})$. The values of skew ness are presented with a normal distribution (at a range +0.5 ), except for the intervals of November (2002-2016) and July-November (2016), which presented a positive asymmetry. Concerning the kurtosis, July stands out with a curve that can be considered as strongly leptokurtic (its values are strongly concentrated around the mean).

In terms of precipitation, July presents the mean and the lowest minimum value when compared with the other sampling months. According to the Student's t-test for the rainfall trends-related independent samples at the MAP-qPCR positive dairy herds of study (material upon request), when the average of the set of historical values (2002-2017) of the sampling months (July to October 2016) are compared with the values presented from each month in the sampling year (2016), it is observed that only July differs significantly from that average.

Considering the bimodal rainfall regime of the region, July is the month in which the second dry season of the year is theoretically presented. November -the reference month for the vegetation analysis, presents significant historical differences with September- only, although in the year of sampling only did not present significant differences with August. However, all sampling months showed significant differences in monthly-accumulated precipitation.

The descriptive results of daytime surface temperature $\left({ }^{\circ} \mathrm{C}\right)$ at the MAP-qPCR positive herds of study (material upon request) showed that the day-time surface temperature for the MAP-qPCR positive herds varied significantly from one day to the next in a given month during the sampling months (between 9.55 and $26.83^{\circ} \mathrm{C}$ ).

The temperature difference between the minimum and the maximum historical record (2002-2016) was even wider (from 5.25 to $28.63^{\circ} \mathrm{C}$ ). According to the Student's t-test for the daytime surface temperature $\left({ }^{\circ} \mathrm{C}\right)$-related independent samples at the MAP-qPCR positive dairy herds of study (material upon request), there were no significant differences between average temperatures among July and August and July and September. 
Data analysis shows that what makes statistically significant differences are those in the minimum values registered, which can reach $4.18^{\circ} \mathrm{C}$ (difference in the minimum values of July and October). The difference between the maximum values reaches at most $0.18^{\circ} \mathrm{C}$ (the difference between the maximum values of July and October). The difference between the average values of July and October reaches $2.14^{\circ} \mathrm{C}$, that is, in the region, a difference of $2.14^{\circ} \mathrm{C}$ is already significant with respect to the day-time surface temperature.

In general terms, the nighttime temperature (although it decreases a lot) usually stays above $0^{\circ} \mathrm{C}$. Independently, the difference in the monthly averages during the sampling months does not exceed $1.1^{\circ} \mathrm{C}$ (material upon request). On the other hand, according to the recent historical data (2002-2016), there may be a difference of up to $34^{\circ} \mathrm{C}$ between a minimum and a maximum surface temperature registered between one date and another.

In the year of sampling, the biggest difference was seen in July $\left(31.84^{\circ} \mathrm{C}\right)$ and the lowest in October $\left(20.06^{\circ} \mathrm{C}\right)$. According to the Student's t-test for the nighttime surface temperature $\left({ }^{\circ} \mathrm{C}\right)$-related independent samples at the MAP-qPCR positive dairy herds of study (material upon request), a significant meandifference between July and October in the recent historical records was reported. However, during the sampling year this difference was not exhibited, so, data were collected under similar circumstances.

\section{DISCUSSION}

Our purpose was to describe the spatial distribution of MAP-infected herds in the study area, as well as to approximate to the appropriate environmental conditions that would potentially lead to an effective detection of MAP, considering the features defined in our methodology, thus proposing the ideal sampling time of the year in tropical countries as Colombia.

Each environmental sample collected during our study contained material from different sites of concentration of adult cattle as well as from wastewater storage lagoons (when available). These collection locations are directly exposed to environmental conditions (for the most part), as well as adult cattle hightraffic areas, being the main reason why the exploration of factors such as rainfall, surface temperature, and vegetation cover was included herein.

Survival of MAP in the environment has been suggested to depend on many factors, including soil type, $\mathrm{pH}$ and moisture, fecal content, and concentrations of macro and micronutrients (e.g. calcium, iron, molybdenum, copper) ${ }^{12,17}$.

Other possibilities include surface water, shade, temperature, and exposure to sunlight $4,9,23,24$. Nevertheless, the results obtained so far from the studies on MAP survival in the environment are very difficult to generalize to the already varied environmental conditions ${ }^{24}$ and due to MAP strain types ${ }^{18}$.
In addition, most studies have been carried out as an experimental model and not as a field study, which does not correspond to real circumstances. And, also, most of these data (not to say all) come from the Northern hemisphere, where livestock are commonly housed indoors during winter on straw bedding, and where climates tend to be milder than in the tropical-temperate grazing regions of Colombia.

Our results showed that an overall high rainfall regime (average of $233.3 \mathrm{~mm} / \mathrm{month}$ ) could favor the detection of the agent in environmental samples of dairy herds infected by MAP in Colombia. July 2016, he month where the vast majority of positive samples were collected, showed the lowest rainfall regime accumulated of the sampling period $(185.8 \mathrm{~mm})$, even though it was still rainy when it was expected to be a dry month, according to historical records and to the theoretical bimodal rainfall regime base.

September 2016 -the month where only one of the positive samples was collected- showed the highest rainfall regime accumulated of the sampling period (306.4 mm), being historically considered as a rainy month. Other authors have reported that the evaluated rainfall amount has a positive effect on the fate of MAP applied to the soil surface with manure slurry.

Under a high rainfall regimen $(2,000 \mathrm{~mm} / \mathrm{year})$, MAP was detected more often from lysimeters with loamy soil than from sandy soil. From these findings, authors concluded that MAP tends to move slowly through soils (faster through sandy soil) and tends to remain on the grass and in the upper layers of pasture soil, representing a clear infection hazard for grazing livestock and a potential for the contamination of runoff after heavy rains. Nevertheless, no effect of the soil moisture on MAP survival has been also reported ${ }^{18}$.

It can be considered that the bimodal rainfall cycle of the region of study is irrelevant in terms of dispersion of MAP, due to the high values of rainfall that occur even in the dry seasons. However, such precipitation could contribute to the dispersion of the bacterium, due to the opportunity of dilution offered by water, and therefore, of dispersion of the contaminated feces, compromising biosecurity measures considered in the control of MAP spread, in and between herds

Our results indicated that the daytime surface temperature presented important variations during sampling months (from 9.55 to $26.83^{\circ} \mathrm{C}$ ) without any tendency to significant differences in and between. July and September 2016 -months where all positive samples were collected- were the ones with the highest daytime surface temperatures during the sample period, with differences of 2.14 and $3.07^{\circ} \mathrm{C}$ compared to the coldest month (October 2016). Nighttime surface temperature showed important variations (-19.37 to 12.47 C), especially during July 2016.

Spatial analysis results showed that areas that exhibit the highest daytime surface temperature also presented the highest nighttime temperature. Nevertheless, considering our data, no hypothetical approaches 
should be detailed about this respect. When comparing the monthly averages of daytime temperatures (t-test), some proximity was observed between the means and the maximum temperatures, but not between the minimum values observed.

This tendency is mainly due to abrupt changes in temperature between day and night and vice versa, which is commonly seen in places where there is not enough vegetation cover or where there is no guarantee of heat retention, which seems to be happening with the grasslands of the study area, according to data. However, nighttime surface temperature offers a kind of homogeneous environment for micobacterium exposed outside the host, regardless of their resistance to temperature changes during the day and in the day-tonight transition.

Even though MAP infection presents a long incubation period inside the host, there is a stage where the bacterium is undoubtedly exposed to the environment, which in general appears to be stressful, considering that the highest daytime surface temperatures areas also present the highest nighttime temperatures, according to the spatial analysis carried out herein.

Visually comparing MAP-qPCR positive vs negative herds, it can be inferred that, with respect to the general thermal environment, MAP has mechanisms of resilience to some extent efficient, for the survival of some local populations, although it does not seem to be enough for a massive dispersion of its metapopulation. This is an aspect that can only be solved through a study design based on the analysis of MAP metapopulation on a monthly-time-series basis, covering its entire biological cycle, with the inherent limitations of such an approach.

According to our results, the study region is characterized by no evidence of management of the vegetation cover, in both pastures and areas with native vegetation, except for a conservancy area, which currently does not make significant differences in terms of density and functional ty pe of vegetation cover with respect to the areas for livestock use. Such vegetation cover features lead to exposed soil, indifferently to the productive purpose of it.

The specific areas with MAP-qPCR positive herds were observed with relatively low humidity (based on the surrounding areas), but a clear pattern in that sense is not highlighted. Our results can be considered as a start point for further designs to solve if the differential vegetation patterns of the study area could increase or diminish MAP population in the environment inside and around the farms.

Then, what is the appropriate natural environment for MAP outside the host, guaranteeing its viable persistence? According to the literature, is a combination of direct and indirect effects of the three variables evaluated in our study. It appears that humid soils ${ }^{22}$, low surface temperature ${ }^{19}$, and shaded areas ${ }^{23,24}$ positively affect MAP survival. Considering our results, it can be inferred that the study area represents a convenient environment for the persistence of MAP outside the host.

In conclusion, our study referred to an exploratory, non-experimental observational study carried out on an uncontrolled tropical and a real dynamic environment. Our purpose was to describe the general conditions of the environmental context where the detection of positive herds is most likely to happen, considering the same (or a very approximate) sample collection and handling, and molecular detection method. In the future, study designs on this disease (or others similar) should be based on spatial probabilistic maps, increasing the chances of finding the causal agent in the environment using less resources.

\section{REFERENCES}

1. Bailey TC, Gatrell AC. 1995. Interactive spatial data analysis, Editorial Routledge (Amazon), 1ra. edición, 432 pag.

2. Collins MT, Gardner IA, Garry FB, Roussel AJ, Wells SJ. 2006. Consensus recommendations on diagnostic testing for the detection of paratuberculosis in cattle in the United States. JAm Vet Med Assoc 229: 12, 1912-1919.

3. Donat $\mathbf{K}$ et al. 2015. Detection of Mycobacterium avium subspecies paratuberculosis in environmental samples by faecal culture and real-time PCR in relation to apparent within-herd prevalence as determined by individual faecal culture. Epidemiol Infect 143: 5, 975-985.

4. Elliott GN, Hough RL, Avery LM, Maltin CA, Campbell CD. 2015. Environmental risk factors in the incidence of Johnes disease. Crit Rev Microbiol 41: 4, 488-507.

5. Fedegan. 2015. Registro de vacunación, primer ciclo. Federación Colombiana de Ganaderos (Fedegan), Boyacá, Colombia (official confidential material).

6. Freitas RM et al. 2011. Virtual laboratory of remote sensing time series: visualization of Modis Evi2 data set over South America. JCIS 2: 1. 57-68

7. Gao BC. 1996. NDWI: a normalized difference water index for remote sensing of vegetation liquid water from space. Remote Sens Environ 58: 257-266.

8. IDEAM. 2012. Mapa de clasificación climática de CaldasLang, República de Colombia, año 2012. Bogotá, DC, Instituto de Hidrología, Meteorología y Estudios Ambientales (IDEAM): Clasificación climática de Lang, 2012.

9. Katayama $\mathbf{N}$ et al. 2004. Influence of ultraviolet-B (UVB) on viability of Mycobacterium avium subsp. paratuberculosis. Grass Forage Sci 50: 336-340.

10. Kruze J, Monti G, Schulze F, Mella A, Leiva S. 2013. Herd-level prevalence of MAP infection in dairy herds of southern Chile determined by culture of environmental fecal samples and bulk-tank milk. Prev Vet Med 111: 3-4, 319-324

11. Kuenstner JT et al. 2017. The consensus from the Mycobacterium avium sp paratuberculosis (MAP). Conference 2017. Front Public Health 5: 208.

12. Larsen AB, Merkal RS, Vardaman TH. 1956. Survival time of Mycobacterium paratuberculosis. Am JVet Res 17: $64,549-551$ 
13. Law DC, Serre ML, Christakos G, Leone PA, Miller WC. 2004. Spatial analysis and mapping of sexually transmitted diseases to optimise intervention and prevention strategies. Sex Transm Infect 80: 4, 294-299.

14. Manning EJ. 2001. Mycobacterium avium subspecies paratuberculosis. J Zoo Wildlife Med 32: 3, 293-304.

15. Pillars RB, Grooms DL, Kaneene JB. 2009. Longitudinal study of the distribution of Mycobacterium avium subsp. paratuberculosis in the environment of dairy herds in the Michigan Johne's disease control demonstration herd project. Can Vet J 50: 10, 1039-1046.

16. Raizman EA et al. 2004. The distribution of Mycobacterium avium sp paratuberculosis in the environment surrounding Minnesota dairy farms. J Dairy $S c i$ 87: 9, 29592966.

17. Rowe MT, Grant IR. 2006. Mycobacterium avium sp paratuberculosis and its potential survival tactics. Lett Appl Microbiol 42: 4, 305-311.

18. Salgado M et al. 2011. Fate of Mycobacterium avium subsp. paratuberculosis after application of contaminated dairy cattle manure to agricultural soils. Appl Environ Microbiol 77: 6, 2122-2129.

19. Schroen C, Kluver PW, Butler KL, Condron RA. 2000. Survival of Mycobacterium paratuberculosis in the environ ment. Meat and Livestock Australia Ltd, North Sydney, Australia, TR.055 (PDF 2.87 MB).

20. Sweeney RW. 1996. Transmission of paratuberculosis. Vet Clin North Am Food Anim Pract 12: 305-312.
21. USDA (United States Department of Agriculture). 2010. Uniform program standards for the voluntary bovine Johne's disease control program. Washington D.C., United States, Department of Agriculture, Animal and Plant Health Inspection Service-APHIS.

22. Whitman WB. 2009. Modern soil microbiology, second edition, Agric Systems 100: 1-3,:89-98.

23. Whittington RJ, Marsh IB, Reddacliff LA. 2005. Survival of Mycobacterium avium subsp. paratuberculosis in dam water and sediment. Appl Environ Microbiol 71: 9, 5304-5308

24. Whittington RJ, Marshall DJ, Nicholls PJ, Marsh IB, Reddacliff LA. 2004. Survival and dormancy of Mycobacterium avium subsp. paratuberculosis in the environment. Appl Environ Microbiol 70: 5, 2989-3004.

25. Wolf R, Barkema HW, Buck J, Orsel K. 2015. Sampling location, herd size, and season influence Mycobacterium avium sp paratuberculosis environmental culture results. J Dairy Sci 98: 1, 275-287.

26. Yengoh GT, Dent D, Olsson L, Tengberg AE, Tucker CJ. 2015. Use of the normalized difference vegetation index (ndvi) to assess land degradation at multiple scales: Current status, future trends, and practical considerations. Springer Briefs in Environmental Science, New York, ISBN 978-3-319-24112-8 